Haemophilus may show Gram variability in staining and often assumes coccal rather than bacillary forms. No other organism commonly seen in the C.S.F. exhibits such marked pleomorphism (Fothergill, 1937). It may readily be mistaken for meningococci or pneumococci. Furthermore, though a heavy growth of $H$. influenzae may be recovered on culture very few or no organisms may be seen in the smear. In none of our patients cases was $H$. influenzae identified in the Gram-stained smear of the C.S.F. deposit and in two (cases 2 and 4) therapy for meningococcal meningitis with penicillin was started on the basis of the appearance of the organism in the Gram-stained film.

There are two main lines of treatment for $H$. influenzae meningitis-either chloramphenicol or high doses of ampicillin given intravenously. Though chloramphenicol treatment is technically the easier it carries a small risk of marrow aplasia. Shackelford et al. (1972) in a comparison of ampicillin and chloramphenicol therapy in patients with $H$. influenzae meningitis found bacteriological relapse occurred in six out of 136 patients treated with ampicillin but in none of the 116 treated with chloramphenicol. They also found that fever was more prolonged and of a greater magnitude in the patients treated with ampicillin. Garrod et al. (1973) conclude that both forms of treatment are generally effective and acceptable.

One can draw few conclusions from the therapy given to our four patients, but it is tempting to speculate that the slow response in the patient in case 1 could have been brought about by possible antagonism between ampicillin and chloramphenicol. In one patient (case 4) high dose ampicillin was given for only 24 hours, and the response to intravenous chloramphenicol was very slow.

Cases of $H$. influenzae meningitis are undoubtedly occurring in adults in the United Kingdom and may not be as rare as was previously supposed. The role of bactericidal antibody in pre- venting the disease is far from clear. Though predisposing causes are sometimes found in these patients this is by no means invariably so. Attention is drawn in particular to the difficulty so often experienced in identifying the organism in the Gramstained deposit of the C.S.F.

We thank Professor W. I. Cranston, Dr. J. B. Harman, and Sir John Richardson for permission to study their cases.

\section{References}

Becker, M. C., and Spingarn, C. L. (1949). American fournal of Medicine, $7,269$.

Davis, D. J. (1909). Archives of Internal Medicine, 4, 323

Dolphin, A., and Popham, R. D. (1951). Lancet, 2, 427 Dyer, R. F., Romansky, M. J., and Holmes, J. R. (1958). Archives of Internal

Feigin, R. D., Richmond, D., Hosler, M. W., and Shackelford, P. G. (1971). American fournal of the Medical Sciences, 262, 338.

Fothergill, L. D., and Wright, J. (1933). Fournal of Immunology, 24, 273. Fothergill, L. D.'(1937). New England Fournal of Medicine, 216, 587.

Garrod, L. P., Lambert, H. P., and O'Grady, F. (1973). Antibiotic and and Chemotherapy, p. 355. London, Churchill Livingstone.

Gladstone, R. M., and Russell, N. A. (1969). Canadian Medical Association Fournal, 101, 61 .

Grant, K. B., Ichaporia, R. N., Joshi, S. K., and Wadia, R. S. (1965). Fournal of the Association of Physicians of India, 13, 619.

Holdsworth, D. E. (1960). Archives of Internal Medicine, 5, 653.

Jervey, L. P. and Charleston, S. C. (1963). Archives of Internal Medicine, 3, 158

Mathies, A. W., Hodgman, J., and Ivler, D. (1965), Pediatrics, 35, 791

Merselis, J. G., Sellers, T. F., Johnson, J. E. (1965) Pediatrics, 35, 791. Archives of Internal Medicine, 110, 73 .

Norden, C. W., Callerame, M. L., and Baum, J. (1970). New England fournal of Medicine, 282, 190.

Public Health Laboratory Service (1973). Unpublished data.

Shackelford, P. G., Bobinski, J. E., Feigin, R. D., and Cherry, J. D., (1972) New England Fournal of Medicine, 287, 634

Stein, J. A., De Rossi, R., and Neu H. C. (1969). New York State fournal of Medicine, 69, 1760 Turk, D. C., and May, J. R. (1967). Haemophilus influenzae, Its Clinical

Turk, D. C. and Wynter, H. H. (1961). West Indian Medical fournal, 10, 118.

\title{
Assessment of Limulus Test for Detecting Endotoxaemia
}

\author{
D. P. FOSSARD, V. V. KAKKAR, PENELOPE A. ELSEY
}

British Medical fournal, 1974, 2, 465-468

\section{Summary}

The occurrence of endotoxaemia in 46 surgical patients has been investigated using a sensitive preparation of limulus lysate. Altogether 23 patients with local and systemic Gram-negative infections were shown to have endotoxaemia. An overt infection is not a prerequisite for a positive limulus test result, since endotoxin can be absorbed via the peritoneal cavity in patients with "chemical" peritonitis. Over $70 \%$ of the tests performed during episodes of Gram-negative infection or peritonitis gave positive results. In 23 patients without clinical evidence of infection or peritonitis only $15 \%$ of the limulus test results were positive. The implications of these findings and the use of the test in clinical practice are discussed.

King's College Hospital Medical School, London SE5 8RX

D. P. FOSSARD, F.R.c.s., Research Fellow and Senior Registrar (Present address: Leicester Royal Infirmary, Leicester)

V. V. KAKKAR, F.R.C.S., IConsultant Surgeon and Senior Lecturer

PENELOPE A. ELSEY, A.I.M.I.T., Research Technician

\section{Introduction}

Endotoxin shock and Gram-negative septicaemia, terms often used synonymously, are increasingly being recognized as complications in both medical and surgical patients. A definitive diagnosis is usually made by obtaining bacteriological evidence of Gram-negative organisms on blood culture, the results of which may not be available for several days. It has become clear, however, that many of the features of shock associated with Gram-negative infections in both experimental animals and man may be produced by endotoxaemia (Cavanagh et al., 1970; Nies et al., 1968).

The limulus test has been suggested as a simple and rapid method of detecting endotoxin or endotoxin-like material (Levin et al., 1970, 1972). The test depends on the ability of endotoxin to produce gelation of an extract of blood cells (amoebocytes) from the horseshoe crab Limulus polyphemus (Bang, 1956). The reliability of this test in clinical practice has been reported with variable results (Levin et al., 1970, 1972; Caridis et al., 1972; Das et al., 1973; Stumacher et al., 1973).

A recent modification of the limulus lysate preparation (Yin et al., 1972) has been shown to be more sensitive in detecting small amounts of endotoxin, and we report here our experience with this lysate in vitro and in clinical practice. 


\section{Materials and Methods}

The studies were performed in two parts. The sensitivity of the lysate was measured in vitro, and clinical investigations were carried out to see whether the limulus test would be useful in detecting endotoxaemia in surgical patients.

\section{ASSESSMENT OF SENSITIVITY OF LYSATE PREPARATIONS}

All glassware used in the test was rendered pyrogen-free. It was first soaked in a detergent (Haemo-Sol) for at least 12 hours and rinsed with tap-water. It was then rinsed eight times with tap-water, eight times with distilled water, and, finally, three times with pyrogen-free water. After this it was then wrapped in aluminium foil and autoclaved at $30 \mathrm{lb} / \mathrm{in}^{2}\left(2 \cdot 1 \mathrm{~kg} / \mathrm{cm}^{2}\right)$ for 20 minutes and then baked in a hot-air oven at $160^{\circ} \mathrm{C}$ for three hours. The aluminium foil wrapper was used as a cap for the $10 \times 75 \mathrm{~mm}$ tubes in which the test was performed. This technique has been found to produce satisfactory glassware (Yin, 1973).

Details of the preparation of limulus lysate have been given elsewhere (Yin et al., 1972).

Endotoxin from Escherichia coli O26·B6 (Boivin) was used throughout the study.

A $10-\mathrm{ml}$ sample of blood was collected in pyrogen-free syringes from each of five healthy volunteers after preparation of the venepuncture sites with $2 \%$ iodine in alcohol. In each of 10 pyrogen-free glass tubes containing 500 units of heparin 5 $\mathrm{ml}$ of blood was placed, the tubes being divided into two groups of five, each containing one sample from each donor.

To one group of five tubes $02.5 \mathrm{ml}$ of $0.9 \%$ saline containing endotoxin $(1 \mu \mathrm{g} / \mathrm{ml})$ was added. The samples were then centrifuged at $800 \mathrm{~g}$ for 10 minutes and the plasma was separated. Serial 10-fold dilutions of each plasma sample were prepared by adding further fresh plasma collected as described above. Seven dilutions were made from each sample.

The second group of blood samples were treated similarly except that the endotoxin was added to the separated plasma and not to the whole blood.

Thus there were 70 plasma samples containing endotoxin at approximate concentrations of $0.1 \mu \mathrm{g} / \mathrm{ml}$ down to $10^{-7}$ $\mu \mathrm{g} / \mathrm{ml}$. From each sample $1 \mathrm{ml}$ was extracted with an equal volume of chloroform by mixing in a vortex mixer for one hour. The mixture was then centrifuged at $1,110 \mathrm{~g}$ for 10 minutes and $0.1 \mathrm{ml}$ of the lower part of the aqueous layer was transferred to a $10 \times 75 \mathrm{~mm}$ pyrogen-free glass tube to which $0.1 \mathrm{ml}$ of limulus lysate was added. The tubes were then incubated at $37^{\circ} \mathrm{C}$ for 24 hours.

A positive result was recorded if there was obvious gelation of the mixture within 24 hours-that is, a solid gel formation or adherence of gel to the side of the tube when tilted to $45^{\circ}$.

\section{CLINICAL STUDIES}

Altogether 46 adult patients admitted to hospital consecutively for elective or emergency surgery were investigated. Their age, sex, and reason for admission are shown in table I. Patients were carefully examined for the presence of intraperitoneal, urinary, or respiratory tract infection. Specimens of blood, sputum, and urine were collected for bacteriological confirmation of the

TABLB I-Details of Patients studied using Limulus Test

\begin{tabular}{|c|c|c|c|}
\hline & & $\begin{array}{l}\text { Clinical Infection } \\
\text { or Peritonitis } \\
(\mathbf{n}=23)\end{array}$ & $\begin{array}{c}\text { No Clinical } \\
\text { Infection } \\
(\mathbf{n}=23)\end{array}$ \\
\hline $\begin{array}{l}\text { No. of men } \quad . \\
\text { No. of women } \quad . \\
\text { Mean age in years (range) } \\
\text { No. of emergency admissions } \\
\text { No. of routine admissions }\end{array}$ & $\begin{array}{l}\ldots \\
\because \\
\because \\
\therefore\end{array}$ & $\begin{array}{c}10 \\
13 \\
64.5(44-86) \\
15 \\
8\end{array}$ & $\begin{array}{c}12 \\
11 \\
61(44-78) \\
8 \\
15\end{array}$ \\
\hline
\end{tabular}

presence of infection. In those patients who had a laparotomy peritoneal fluid was obtained and examined for the presence of organisms. All specimens were cultures for aerobic and anaerobic organisms.

\section{LIMULUS TEST}

Frequent blood samples were obtained from all the patients investigated. The tests were performed as described above and were carried out by one of us (P.E.), who was not aware of the clinical or bacteriological findings in any patient. In all tests performed negative controls with normal plasma or pyrogen-free water and positive controls with endotoxin solution $\left(10^{-3}\right.$ $\mu \mathrm{g} / \mathrm{ml}$ ) added to the lysate were used. Unless these controls gave the expected results the tests were discarded and repeated.

\section{Results}

\section{SENSITIVITY OF LYSATE PREPARATION}

When endotoxin was dissolved in saline the limulus test gave a positive result with as little as $10^{-5} \mu \mathrm{g} / \mathrm{ml}$, and similar results were obtained using endotoxin dissolved in plasma. When using whole blood as a solvent, and assuming that all the endotoxin is present in the plasma, the limulus test gave a positive result down to a concentration of $10^{-3} \mu \mathrm{g} / \mathrm{ml}$ of plasma (table II).

TABLE II-Results of Limulus Test in Vitro using Three Solvents*

\begin{tabular}{|c|c|c|c|c|c|c|c|c|}
\hline & & \multicolumn{7}{|c|}{ Limulus concentration $\mu \mathrm{g} / \mathrm{ml}$ : } \\
\hline & & $0 \cdot 1$ & $10-3$ & $10-^{3}$ & $10-4$ & $10-5$ & $10-^{\circ}$ & $10-7$ \\
\hline $\begin{array}{l}\text { Saune } \\
\text { Plasma } \\
\text { Blood }\end{array}$ & $\begin{array}{l}\cdots \\
\cdots\end{array}$ & $\begin{array}{l}+++ \\
+++ \\
+++\end{array}$ & $\begin{array}{c}+++ \\
++ \\
++\end{array}$ & $\begin{array}{c}++ \\
++ \\
+\end{array}$ & $\begin{array}{c}++ \\
+ \\
+\end{array}$ & $\begin{array}{l}+ \\
\pm\end{array}$ & $\bar{z}$ & $\bar{z}$ \\
\hline
\end{tabular}

* Results of 5 tests with each solvent: $+++=$ solid gel in 2 hours; $++=$ solid gel in 24 hours; $+=$ viscous gel in 24 hours.

\section{CLINICAL STUDIES}

Of the 46 patients studied 17 were diagnosed clinically as having a local infection (table III), 6 had generalized peritonitis, and 23 had no clinical evidence of infection or peritonitis.

Pathogenic organisms were cultured from various sources in 16 of the 17 patients with a local infection. In all these cases Gram-negative organisms were obtained (table III). In these patients 64 limulus tests were performed during the episode of infection, of which $46(72 \%)$ gave positive results. Out of 31 tests performed after the infection had been adequately treated only $1(3 \%)$ gave a positive result.

Of the six patients with generalized peritonitis three had perforated duodenal ulcers and three had acute pancreatitis (table IV). In these patients bacteriological culture of the peritoneal fluid of blood failed to isolate any organisms, but 13 out of 17 limulus tests $(76 \%)$ gave positive results at the time of the peritonitis. Of the 11 tests performed subsequently, when clinical signs of the peritonitis had disappeared, $2(18 \%)$ gave positive results.

In 23 patients there was no clinical evidence of infection or peritonitis. Bacteriological specimens were obtained from 14 and in five positive cultures were obtained (table V). Three of these were Gram-negative organisms and two were Gram-positive. Out of 117 limulus tests performed in this group $17(15 \%)$ gave positive results; five of these were obtained from one patient. The patient had a reversed ileal loop operation performed previously for intractable diarrhoea and suffered recurrent attacks of subacute intestinal obstruction. The five positive results were obtained during two such attacks, and after resection of the reversed loop the limulus test gave negative results on three occasions. 
TABLE III-Results of Limulus Test in Patients with Clinical and bacteriological Infection

\begin{tabular}{|c|c|c|c|c|c|}
\hline \multirow[b]{2}{*}{$\begin{array}{l}\text { Case } \\
\text { No. }\end{array}$} & \multirow{2}{*}{ Diagnosis } & \multicolumn{2}{|c|}{$\begin{array}{l}\text { No. of Positive Results/ } \\
\text { No. of Tests Performed }\end{array}$} & \multirow{2}{*}{ Organism } & \multirow{2}{*}{ Source } \\
\hline & & $\begin{array}{c}\text { During } \\
\text { Infection }\end{array}$ & $\begin{array}{c}\text { After } \\
\text { Infection }\end{array}$ & & \\
\hline 1 & Appendicitis & $4 / 4$ & $0 / 1$ & Enterobacter & Appendix and \\
\hline $\begin{array}{l}2 \\
3 \\
4 \\
5 \\
6\end{array}$ & $\begin{array}{l}\text { Carcinoma colon wound infection } \\
\text { Diverticulitis } \\
\text { Acute cholecystitis } \\
\text { Pericolic abscess } \\
\text { Ischiorectal abscess }\end{array}$ & $\begin{array}{l}3 / 3 \\
2 / 2 \\
3 / 3 \\
4 / 4 \\
5 / 8\end{array}$ & $\begin{array}{l}0 / 3 \\
1 / 6 \\
0 / 1 \\
0 / 3\end{array}$ & $\begin{array}{l}\text { Bacteroides } \\
\text { No growth } \\
\text { Escherichia coli } \\
\text { Proteus } \\
\text { E. coli, } \\
\text { Bacteroides }\end{array}$ & $\begin{array}{l}\text { Wound } \\
\text { Wrine } \\
\text { Brile } \\
\text { Abscess } \\
\text { Wound }\end{array}$ \\
\hline 7 & Pararectal a uscess, septicaemia & $4 / 4$ & Died & $\begin{array}{l}\text { Pseudomonas } \\
\text { aeruginosa }\end{array}$ & $\begin{array}{l}\text { Blood } \times 3, \\
\text { sputum, wound }\end{array}$ \\
\hline $\begin{array}{r}8 \\
9 \\
10 \\
11\end{array}$ & $\begin{array}{l}\text { Cholecystitis } \\
\text { Pyosalpint } \\
\text { Cholecystitis } \\
\text { Obstructive jaundice, respiratory infection }\end{array}$ & $\begin{array}{l}1 / 2 \\
2 / 3 \\
0 / 2 \\
3 / 3\end{array}$ & $\begin{array}{l}0 / 8 \\
0 / 1 \\
0 / 2 \\
0 / 2\end{array}$ & $\begin{array}{l}\text { E. coli } \\
\text { E. coli } \\
\text { E. coli } \\
\text { Ps. aeruginosa, } \\
\text { Klebsiella }\end{array}$ & $\begin{array}{l}\text { Bile } \\
\text { Abscess } \\
\text { Bile } \\
\text { Sputum }\end{array}$ \\
\hline 12 & Respiratory infection, peritonitis & $4 / 6$ & Died & $\begin{array}{l}\text { Hemophilus } \\
\text { infl:tenzae }\end{array}$ & $\begin{array}{l}\text { Sputum } \\
\text { Peritoneal } \\
\text { Fluid }\end{array}$ \\
\hline 13 & Urinary tract infection, carcinoma colon & $4 / 4$ & $0 / 2$ & $\begin{array}{l}\text { Serratia } \\
\text { marcescens, } \\
\text { Enterobacter }\end{array}$ & $\begin{array}{l}\text { Urine } \\
\text { Urine } \times 6\end{array}$ \\
\hline $\begin{array}{l}14 \\
15 \\
16\end{array}$ & $\begin{array}{l}\text { Carcinoma rectum, septicaemia } \\
\text { Urine infection, renal stones } \\
\text { Appendicitis }\end{array}$ & $\begin{array}{l}4 / 4 \\
1 / 4 \\
1 / 4\end{array}$ & $\begin{array}{l}\text { Died } \\
0 / 1\end{array}$ & $\begin{array}{l}\text { E. coli } \\
\text { E. coli } \\
\text { E. coli }\end{array}$ & $\begin{array}{l}\text { Blood } \times 3 \text {, wound } \\
\text { Urine } \times 3 \text {. } \\
\text { Appendix and }\end{array}$ \\
\hline 17 & Appendicitis & $1 / 4$ & $0 / 1$ & E. coli & Appendix \\
\hline & Total & $46 / 64(72 \%)$ & $1 / 31(3 \%)$ & & \\
\hline
\end{tabular}

TABLE IV-Results of Limulus Test in Patients with Peritonitis

\begin{tabular}{|c|c|c|c|c|c|}
\hline \multirow[b]{2}{*}{$\begin{array}{l}\text { Case } \\
\text { No. }\end{array}$} & \multirow{2}{*}{ Diagnosis } & \multicolumn{2}{|c|}{$\begin{array}{l}\text { No. of Positive Results/ } \\
\text { No. of Tests Performed }\end{array}$} & \multirow{2}{*}{ Organism } & \multirow{2}{*}{ Source } \\
\hline & & $\begin{array}{c}\text { During } \\
\text { Peritonitis }\end{array}$ & $\begin{array}{c}\text { After } \\
\text { Peritonitis }\end{array}$ & & \\
\hline \multirow[t]{2}{*}{$\begin{array}{l}18 \\
19 \\
20 \\
21 \\
22 \\
23\end{array}$} & $\begin{array}{l}\text { Perforated duodenal ulcer } \\
\text { Perforated duodenal ulcer } \\
\text { Perforated duodenal ulcer } \\
\text { Acute pancreatitis } \\
\text { Acute pancreatitis } \\
\text { Acute pancreatitis }\end{array}$ & $\begin{array}{l}1 / 2 \\
2 / 3 \\
2 / 2 \\
3 / 4 \\
3 / 3 \\
2 / 3\end{array}$ & $\begin{array}{l}1 / 2 \\
0 / 2 \\
1 / 2 \\
0 / 2 \\
0 / 2 \\
0 / 1\end{array}$ & $\begin{array}{l}\text { No growth } \\
\text { No growth } \\
\text { No growth } \\
\text { No growth } \\
\text { No growth }\end{array}$ & $\begin{array}{l}\text { Peritoneal fluid } \\
\text { Peritoneal fluid } \\
\text { Peritoneal fluid } \\
\text { Blood } \times 2 \\
\text { Blood } \times 2\end{array}$ \\
\hline & Total & $13 / 17(76 \%)$ & $2 / 11(18 \%)$ & & \\
\hline
\end{tabular}

TABLE v-Results of Limulus Test in Patients with No Clinical Evidence of Infection

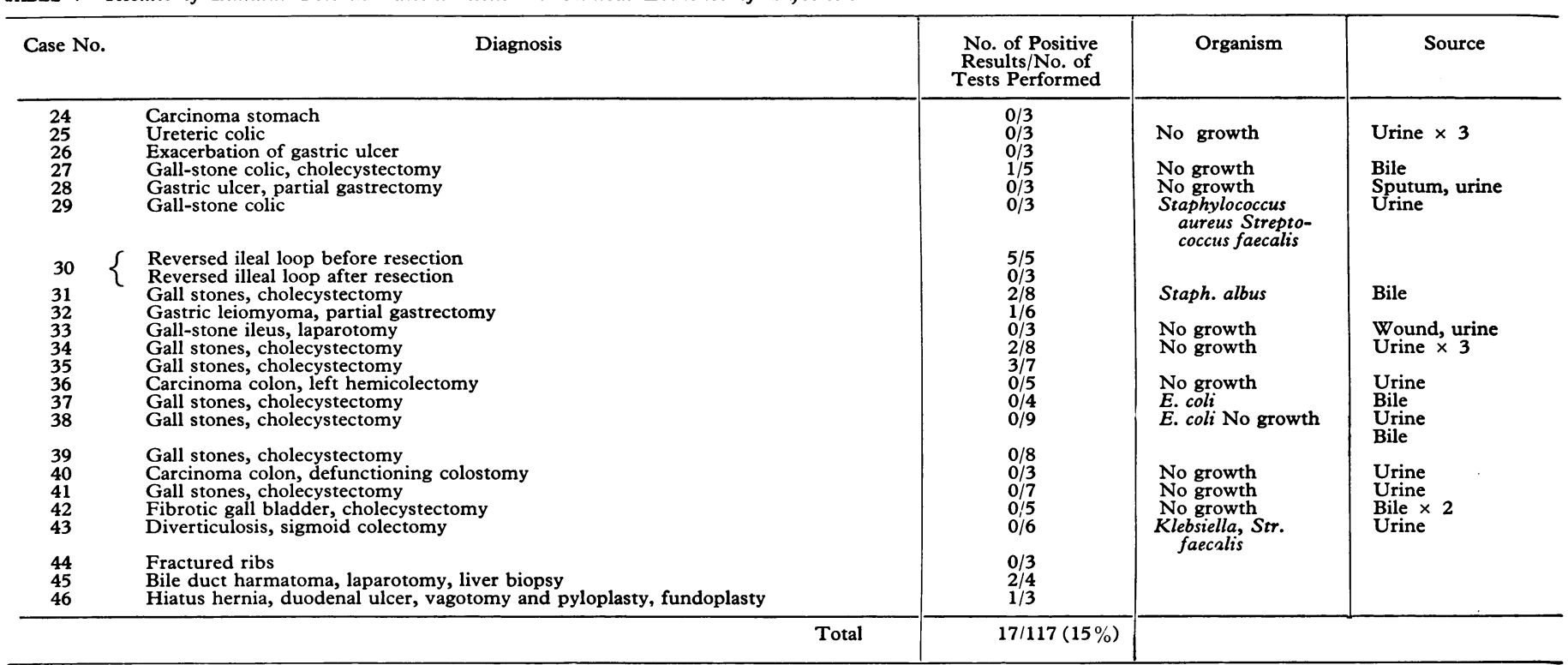

\section{Discussion}

"Endotoxic shock" is being recognized by clinicians and pathologists as an increasingly common cause of morbidity and mortality in hospital patients. Objective diagnosis can be difficult but is important because of the potentially lethal consequences of the condition, particulary in those patients whose defence mechanisms are impaired, such as in liver failure or after renal transplantation. Blood cultures are unreliable, and though they may detect bacteraemia this is not a sine qua non of endotoxaemia. The need for a simple and rapid diagnostic test for endotoxaemia is therefore apparent.

The recent modification of the technique for preparing the limulus lysate (Yin et al., 1972) has increased its sensitivity as measured in vitro. Using a relatively crude preparation of endotoxin we have shown that concentrations as low as $10^{-5}$ $\mu \mathrm{g} / \mathrm{ml}$ may be detected when the endotoxin is dissolved in water or saline. The test loses some of its sensitivity, however, when 
the endotoxin is dissolved in whole blood. This is probably due to uptake of the endotoxin by platelets (Herring et al., 1963; Das et al., 1973).

The limulus test appears to fulfill most of the criteria for a simple test for detecting endotoxin in vivo. Recent reports on the value of the test in clinical practice have varied. Levin et al. $(1970,1972)$ are of the opinion that the test is useful but that endotoxaemia and bacteraemia may not occur concurrently. Stumacher et al. (1973) had reservations about its value as a test for the detection of Gram-negative infection. It is apparent that those who report a good correlation between a positive test result and the presence of Gram-negative infection have used the test in selected patients (Levin et al., 1970, 1972; Das et al., 1973), whereas Stumacher et al. (1973) studied a more general population but did not furnish any clinical information about their patients, which may have helped to establish a relation between the results of the limulus test and other pathological processes. Caridis et al. (1972) provided detailed clinical information on some patients and related this to the findings of the limulus test.

In our study $72 \%$ of the limulus tests performed on blood samples from patients with active local or systemic Gram negative infections gave positive results. After the patients had recovered clinically only one positive result was obtained. These figures indicate that Gram-negative infection is not always accompanied by a persistent endotoxaemia, and because of its transient nature the limulus test should be repeated if reliable results are to be obtained.

Endotoxaemia also occurs in the absence of Gram-negative infection, and in the six patients in this series with "chemical peritonitis" $76 \%$ of the limulus tests gave positive results, the figure falling to $18 \%$ after the signs of peritonitis had settled. It has been postulated that endotoxin may be released from abnormally permeable bowel and absorbed into the circulation via the peritoneal cavity. Fine et al. produced experimental evidence which provides the basis for this hypothesis (Tamakuma et al., 1971; Cuevas and Fine, 1972) and our findings lend it clinical support.

In the 23 patients without overt Gram-negative infection or peritonitis $15 \%$ of the limulus tests gave positive results. Though precautions were taken to ensure that contamination of the glassware and lysate did not occur, by performing simultaneous control tests contamination of the specimen during collection cannot be entirely ruled out. The other possibility is that the limulus lysate is sensitive to the presence of such small quantities of endotoxin; it is quite possible that these patients did have endotoxaemia but not in amounts sufficient to cause clinical symptoms or signs. This is almost certainly true of the patient with the reversed ileal loop, who had five positive test results before the loop was excised.

We feel that the limulus test is a simple, rapid, and reliable method for the detection of endotoxaemia, particularly when it is repeated frequently during the episode of infection. The clinical significance of small amounts of circulating endotoxins detected by the method has yet to be determined. It is possible that the tests may be useful for assessing the response of treatment to control Gram-negative infection and as a screening procedure for the presence of endotoxaemia in patients at high risk of developing endotoxic shock. Early and vigorous treatment at this stage may reduce the mortality and morbidity due to this contion. Furthermore, it may also prove useful in relating the pathophysiological changes which occur in patients to the presence of endotoxaemia. We are at present engaged in investigating these possibilities.

We thank the consultant physicians and surgeons of King's College Hospital for allowing us to study their patients, the King's College Hospital Research Trust for financial support, and Dr. S. Wessler and Dr. E. T. Yin, of the Jewish Hospital of St. Louis, Missouri, U.S.A., for supplies of limulus lysate. We also thank Mrs. G. Shelton for secretarial help.

\section{References}

Bang, F. B. (1956). Bulletin of the fohns Hopkins Hospital, 98, 325.

Caridis, D. T., Reinhold, R. B., Woodruff, P. W. H., and Fine, J. (1972). Lancet, 1,1381.

Cavanagh, D., Rao, P. S., Sutton, D. M. G., Bhagat, B. D., and Bachman, F. (1970). American fournal of Obstetrics and Gynecology 108, 705.

Cuevas, P., and Fine, J. (1972). Surgery, Gynecology and Obstetrics, 134, 953.

Das, J., Schwartz, A. A., and Folkman, J. (1973). Surgery, 74, 235.

Herring, W. B., Herion, J. C., Walker, R. I., and Palmer, J. G. (1963). Fournal of Clinical Investigation, 42, 79.

Levin, J., Poore, T. E., Zauber, N. P., and Össer, R. S. (1970). New England fournal of Medicine, 283, 1313.

Levin, I., et al. (1972). Annals of Internal Medicine, 76, 1.

Nies, A., et al. (1972. Annals ofliams, H. E., and Melmon, K. L. (1968) Clinical Research, 22, 155 .

Stumacher, R. J., Kovnat, M. J., and McCabe, W. R. (1973). New England fournal of Medicine, 288, 1261 .

Tamakuma, S., Rojas-Corona, R., Cuevas, P., and Fine, J. (1971). Annals of Surgery, 173, 219.

Yin, E. T. (1973). Personal communication.

Yin, E. T., et al. (1972). Biochimica et Biophysica Acta, 261, 284.

\title{
Sequelae of an ${ }^{125 I-F i b r i n o g e n ~ D e t e c t e d ~ T h r o m b u s ~}$
}

\author{
N. L. BROWSE, G. CLEMENSON
}

British Medical fournal, 1974, 2, 468-470

\section{Summary}

Forty-four patients who had a deep vein thrombosis detected with the fibrinogen uptake test were followed up three to four years later. The mild aching pains and ankle swelling that were present at the time of the thrombosis persisted or got worse in many, but there was no increase in the incidence of varicose veins. The minor self-limiting thrombosis detected with the fibrinogen uptake test should not be considered innocuous, for it can cause long-lasting symptoms.

Department of Surgery, St. Thomas's Hospital, London SE1 7EH N. L. BROWSE, M.D., F.R.C.s., Professor of Vascular Surgery G. CLEMENSON, Research Assistant

\section{Introduction}

The development of the fibrinogen uptake test into a practical clinical test by Atkins and Hawkins (1965), Flanc et al. (1968), and Negus et al. (1968) enable us to detect the many small thrombi that occur in the leg veins after surgery and medical .illnesses. Studies in many centres showed that though small thrombi are common most do not propagate but gradually disappear. So common is this self-limiting calf vein thrombosis that those using the fibrinogen uptake test adopted a policy of treating only those thrombi that extended beyond the calf or began above the level of the knee joint, on the assumption that a small calf thrombus was unlikely to become a serious embolus or significantly disturb the functions of the peripheral veins. No one has published a late follow-up of the state of the limbs of patients who have had a positive fibrinogen uptake test result, however, and this study attempts to remedy this deficiency. 